\title{
Activation of Toll-Like Receptor 2 Promotes Proliferation of Human Lung Adenocarcinoma Cells
}

\author{
ANNA K. GERGEN, PATRICK D. KOHTZ, ALISON L. HALPERN, ANQI LI, XIANZHONG MENG, \\ T. BRETT REECE, DAVID A. FULLERTON and MICHAEL J. WEYANT \\ Division of Cardiothoracic Surgery, Department of Surgery, \\ University of Colorado School of Medicine, Aurora, CO, U.S.A.
}

\begin{abstract}
Background/Aim: The aim of this study was to evaluate the role of toll-like receptor 2 (TLR2) in the proliferation of human lung cancer cells and identify the signaling pathway that mediates this effect. Materials and Methods: Adenocarcinoma (A549 and H1650) and adenosquamous (H125) cells were treated with increasing doses of Pam3CSK4, a TLR2 agonist. Cell proliferation and NF-kB activation were evaluated. $\mathrm{NF}-\mathrm{k} B$ was inhibited prior to treatment with Pam3CSK4 and proliferation was assessed. Results: TLR2 expression was significantly higher in A549 and H1650 cells compared to H125 cells $(p<0.001)$. TLR2 stimulation induced proliferation in adenocarcinoma cells only and led to a corresponding increase in $N F-k B$ activity $(p<0.05)$. Inhibition of $N F-k B$ prior to treatment with Pam $3 C S K 4$ attenuated this proliferative response. Conclusion: TLR2 activation induced proliferation of lung adenocarcinoma cells through activation of $N F-k B$. Thus, the TLR2 signaling pathway may be a potential therapeutic target in lung adenocarcinoma.
\end{abstract}

In the United States, cancer is the second leading cause of death for all ages and the leading cause of death for adults aged 40 years and older. Lung cancer is the second most common cancer and the most lethal cancer in both men and women, accounting for nearly $25 \%$ of all cancer-related deaths (1). Despite advancements in various medical and surgical treatment options, long-term survival remains a significant challenge (2). Small cell and non-small cell lung

This article is freely accessible online.

Correspondence to: Anna K. Gergen, MD, Division of Cardiothoracic Surgery, Department of Surgery, University of Colorado School of Medicine, 12631 E. 17th Avenue, MS C-302, Aurora, CO 80045, U.S.A. Tel: +1 2063847837, Fax: +1 3037242806, e-mail: anna.gergen@cuanschutz.edu

Key Words: Lung cancer, non-small cell lung cancer, lung adenocarcinoma, toll-like receptor 2, nuclear factor-kappa B, proliferation. cancer (NSCLC) are the two primary types of lung cancer in the United States, with $85 \%$ of cases classified as NSCLC (3). Adenocarcinoma represents the predominant subtype of NSCLC, accounting for $34 \%$ of male and $41 \%$ of female lung cancer diagnoses in the United States.

Innate immunity has been implicated in the pathogenesis of multiple different malignancies, with many novel therapeutic targets aimed at modulating specific components of the immune system $(4,5)$. Although certain aspects of the innate immune system have been studied and successfully targeted in NSCLC, these initial efforts have only made a small impact in the treatment success for patients with $\operatorname{NSCLC}(6,7)$. Tolllike receptors (TLRs) are a family of proteins that play a key role in the innate immune system by recognizing pathogenassociated molecular patterns, or PAMPs. Dysregulation of TLR signaling within the gastrointestinal tract has been associated with cancer development (8-10). Additionally, previous work by our group has demonstrated a potential role of TLRs in the development and progression of esophageal adenocarcinoma $(11,12)$.

Growing evidence suggests that TLRs may serve as prognostic markers in NSCLC, with the degree of TLR expression correlating with overall survival (13). Pam3CSK4, a highly-specific synthetic agonist of toll-like receptor 2 (TLR2), mimics bacterial lipoproteins commonly present in the cell walls of gram-positive and gram-negative bacteria (14-16). Gowing et al. demonstrated that grampositive pneumonia can stimulate rapid growth of human lung cancer cells via a TLR2-mediated response (17). In addition, TLR2 has been demonstrated to serve as a specific mediator between lung cancer cells and mesenchymal stem cells present within the tumor microenvironment, facilitating cross-talk that ultimately promotes tumor-supportive phenotypic changes of mesenchymal cells (18).

The specific role and mechanism of TLR2 in promoting tumor growth in NSCLC remains unclear. This study aimed to evaluate TLR2 expression levels in NSCLC subtypes and examine the influence of TLR2 on the growth and proliferation of human lung cancer cells. We hypothesized 
that TLR2 activation promotes proliferation of lung cancer cells via activation of nuclear factor kappa B (NF-kB).

\section{Materials and Methods}

Cells and reagents. A549 and $\mathrm{H} 1650$ cell lines were obtained from American Type Culture Collection (Manassas, VA, USA), while the H125 cell line was obtained from the University of Colorado Cancer Center Tissue Culture Core (Aurora, CO, USA). All cell lines were maintained in Roswell Park Memorial Institute Medium (RPMI 1640; Gibco, Grand Island, NY, USA) supplemented with $10 \%$ fetal bovine serum (FBS), $0.5 \%$ penicillin/streptomycin, and gentamicin/amphotericin (1:500 dilution). Serum-reduced media contained $1 \%$ FBS, $0.5 \%$ penicillin/streptomycin, and gentamicin/amphotericin (1:500 dilution). Cells were incubated at $37^{\circ} \mathrm{C}$ in humidified $95 \%$ air and $5 \%$ carbon dioxide.

Western blot antibodies included phosphorylated NF-kB, total NF-kB, and glyceraldehyde-3-phosphate dehydrogenase (GAPDH) from Cell Signaling Technology (Beverly, MA, USA), as well as toll-like receptor 4 (TLR4) from Santa Cruz Biotechnology (Dallas, TX, USA) and TLR2 from Boster Biological Technology (Pleasanton, CA, USA). GAPDH was used as the housekeeping protein to standardize protein concentrations for all western blots. Western blot antibodies were diluted in $4 \%$ bovine serum albumin (BSA). For immunofluorescence microscopy, we utilized the NF-kB p65 (D14E12) XP ${ }^{\circledR}$ (Cell Signaling Technology, Beverly, MA, USA) antibody. This antibody was diluted in phosphate-buffered saline (PBS) containing 1\% BSA. The TLR2 agonist Pam3CSK4 (InvivoGen USA, San Diego, CA, USA) was dissolved in $1 \mathrm{ml}$ of molecular grade sterile water for a stock concentration of $1 \mathrm{mg} / \mathrm{ml}$.

Western blotting. This technique was adapted from previously published studies $(11,19,20)$. Following cell treatments, cells were washed with PBS twice followed by lysis with $2 x$ Laemmli Sample Buffer (Bio-Rad, Hercules, CA, USA) containing 5\% 2mercaptoethanol. Cell lysates were heated and loaded into a 4$20 \%$ linear gradient polyacrylamide gel, and proteins were separated using sodium dodecyl sulfate-polyacrylamide gel electrophoresis. Proteins were then transferred to nitrocellulose membranes and membranes were then blocked with PBS-Tween 20 containing 5\% non-fat milk for $1 \mathrm{~h}$. Membranes were probed for the aforementioned primary antibodies and incubated overnight at $4^{\circ} \mathrm{C}$. Rabbit and mouse secondary antibodies were diluted in PBS-Tween 20 with 5\% non-fat milk and allowed to incubate for $1 \mathrm{~h}$. Membranes were developed with SuperSignal ${ }^{\mathrm{TM}}$ West Dura Extended Duration Substrate (Thermo Fisher Scientific, Waltham, MA, USA) using Image Lab 5.0 Software (Bio-Rad, Hercules, CA, USA). Protein densitometric analysis was performed with ImageJ Software (National Institutes of Health, Bethesda, MD, USA).

Cell proliferation assay. Cells were plated on 96-well plates at a concentration of $1^{\prime} 10^{5}$ cells/well. Following cell treatments, cell proliferation was evaluated using the MTS Cell Proliferation Colorimetric Assay Kit according to manufacturer's instructions (BioVision Incorporated, Milpitas, CA, USA). Briefly, $20 \mu \mathrm{l}$ of MTS reagent was added to each well and allowed to incubate at $37^{\circ} \mathrm{C}$ for $30 \mathrm{~min}$. Following incubation, optical density was read at $490 \mathrm{~nm}$ using a microplate reader.

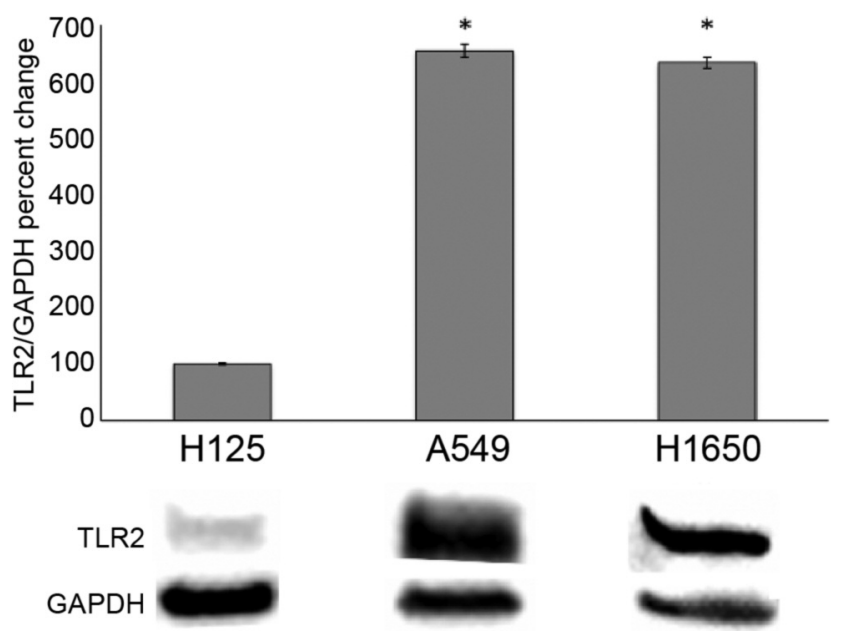

Figure 1. Baseline TLR2 expression is significantly higher in adenocarcinoma cells (A549 and H1650) compared to adenosquamous cells (H125). $n=6$. * $p<0.001$ to H125. GAPDH: Glyceraldehyde-3phosphate dehydrogenase; TLR2: toll-like receptor 2 .

Enzyme-linked immunosorbent assay (ELISA). NF-kB activation in nuclear extracts was measured using the Active Motif TransAM ${ }^{\circledR}$ NF$\mathrm{kB}$ Family ELISA kit according to manufacturer's instructions (Carlsbad, CA, USA). In brief, following cell treatments, $5 \mu \mathrm{g}$ of nuclear extracts from each sample were collected and incubated in a 96-well plate coated with immobilized NF-KB consensus oligonucleotides for $1 \mathrm{~h}$. The ELISA plate was washed three times with wash buffer and then incubated with primary antibodies against the NF-kB subunit $\mathrm{p} 65$ for $1 \mathrm{~h}$. The plate was washed again three times with wash buffer followed by incubation with an HRP-conjugated secondary antibody for $1 \mathrm{~h}$. An HRP substrate was added causing a colorimetric reaction and absorbance was measured at $450 \mathrm{~nm}$.

Immunofluorescence. Cells were plated at $5^{\prime} 10^{4}$ cells/chamber in Lab-Tek ${ }^{\circledR}$ Chamber Slide ${ }^{\mathrm{TM}}$ 8-well glass slides (Thermo Fisher Scientific, Waltham, MA, USA) and incubated for $24 \mathrm{~h}$ prior to the start of cell treatments. Imaging was performed as previously described with the following modifications: following treatments, plates were rinsed with PBS two times, permeabilized with $70 \%$ methanol/30\% acetone for $5 \mathrm{~min}$, washed with PBS, allowed to dry, and fixed with $4 \%$ paraformaldehyde for $15 \mathrm{~min}(19,21,22)$. Slides were then washed with PBS and blocked in $10 \%$ rabbit serum for $30 \mathrm{~min}$. Slides were incubated with primary antibody overnight at $4^{\circ} \mathrm{C}$ using the above-mentioned NF-kB p65 antibody $(5 \mu \mathrm{g} / \mathrm{ml})$. After washing with PBS, slides were incubated with Cy3-conjugated secondary antibody for $2 \mathrm{~h}$ at room temperature. Bis-benzimide staining of nuclei (4',6-diamidino-2-phenylindole, DAPI) was imaged on the blue channel, while NF-kB staining was imaged on the red (Cy3) channel. Microscopic photography was performed with a Leica CTR5500 digital microscope (Leica Mikroskopie und Systeme GmbH, Wetzlar, Germany).

Measurement of baseline TLR2 expression. Cells were plated onto 12 -well plates at a density of $2 \times 10^{5}$ cells/well and grown in full strength RPMI until $80 \%$ confluence was achieved. The cells were then serum-reduced for $24 \mathrm{~h}$ followed by cell lysis for western blot 

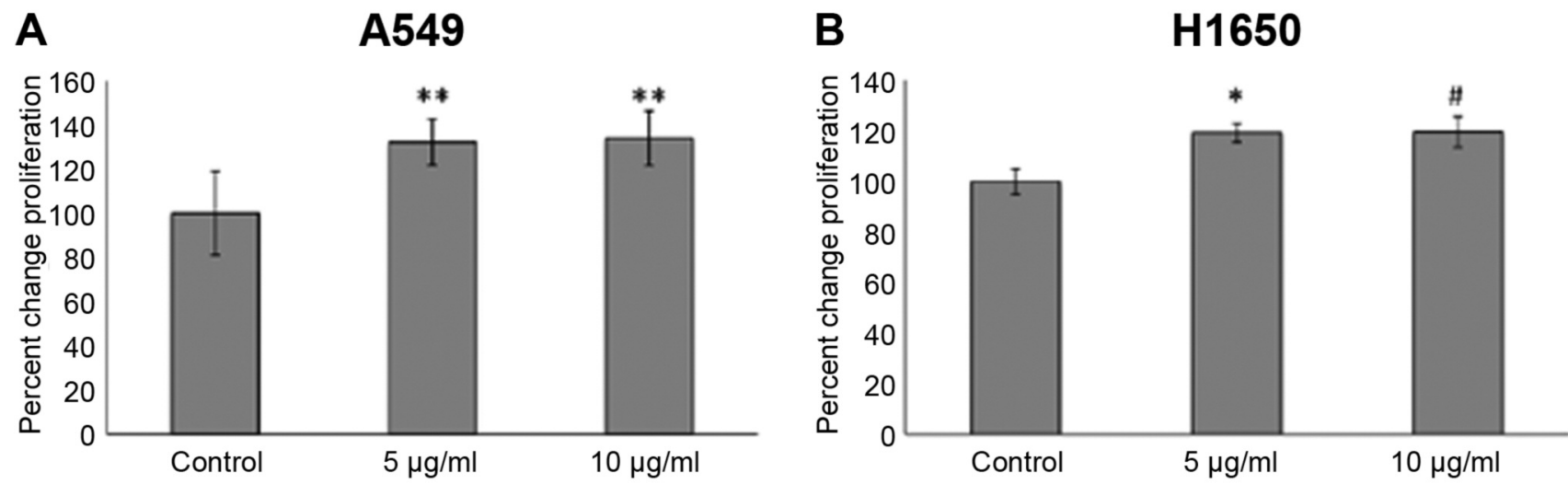

\section{C}

\section{H125}

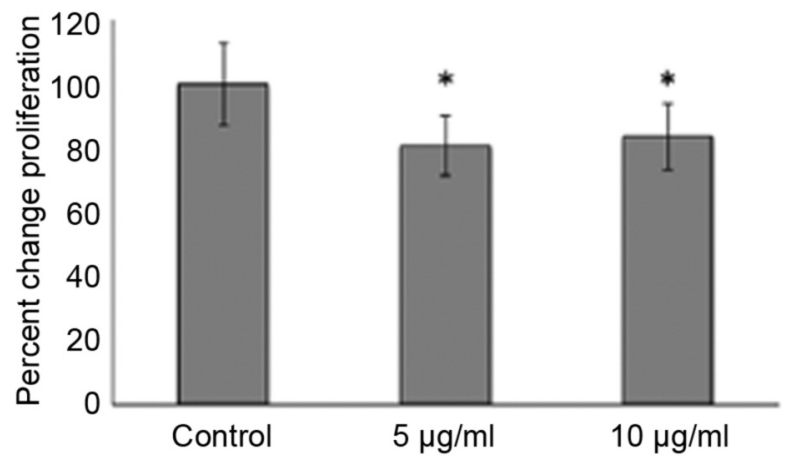

Figure 2. Following TLR2 stimulation with Pam3CSK4, cell proliferation significantly increased in A) A549 and B) H1650 adenocarcinoma cell lines. C) In H125 adenosquamous cells, proliferation significantly decreased following TLR2 activation. $n=8 . * p<0.05, * * p<0.01$, $\# p<0.001$ to control. TLR2: Toll-like receptor 2 .

analysis. For cells undergoing immunofluorescence, cells were serum-reduced for $24 \mathrm{~h}$ followed by development.

Cell proliferation following TLR2 activation. Cells were plated on 96-well plates at a concentration of $1 \times 10^{5}$ cells/well. Cells were treated with Pam3CSK4 $(0 \mu \mathrm{g} / \mathrm{ml}, 5 \mu \mathrm{g} / \mathrm{ml}, 10 \mu \mathrm{g} / \mathrm{ml})$ diluted in serum-reduced media for $48 \mathrm{~h}$. The MTS proliferation assay was performed as described above.

Measurement of NF-KB activity following TLR2 activation. Cells were stimulated with Pam3CSK4 at a dose of $10 \mu \mathrm{g} / \mathrm{ml}$ diluted in serum-reduced media for increasing time periods $(5,10,30 \mathrm{~min}, 1$, $2,4,8$, and $24 \mathrm{~h}$ ). Controls were incubated in serum-reduced media without Pam3CSK4 for $24 \mathrm{~h}$. Cells were then lysed for western blot or ELISA analysis. Phosphorylated NF-KB, total NF-kB, and GAPDH protein expression were measured at each time point. Immunofluorescence microscopy for NF-kB p65 subunit was performed following treatment with $10 \mu \mathrm{g} / \mathrm{ml} \mathrm{Pam3CSK} 4$ for 15 , 30, and $60 \mathrm{~min}$. Controls were treated with serum-reduced media without Pam3CSK4 for $1 \mathrm{~h}$.

Cell proliferation following NF- $k B$ inhibition and TLR2 activation. Cells were treated with Bay 11-7082 (5 and $25 \mu \mathrm{M}$ in DMSO), vehicle control (DMSO 0.005\%), or negative control (serum-reduced media) followed by treatment with $10 \mu \mathrm{g} / \mathrm{ml}$ Pam3CSK 4 for $48 \mathrm{~h}$. The MTS proliferation assay was performed as described above.

Statistical analysis. For all western blot results, the density of the band of interest was divided by the density of GAPDH from the same membrane to create a normalized ratio. The normalized ratio of each treatment group was then divided by the normalized ratio of the control from the same experimental plate and multiplied by 100 , giving the control an adjusted percentage value of 100. For western blot results involving NF-kB, the phosphorylated and total protein densities were normalized to their respective GAPDH. The normalized phosphorylated protein ratio was then divided by the normalized total protein ratio. This value was divided by the normalized ratio of the control from the same experimental plate and then multiplied by 100 , giving the control an adjusted percentage value of 100 . For cell proliferation results, the absorbance value of each well was divided by the absorbance value of the control and multiplied by 100 , giving the control an adjusted percentage value of 100 . By normalizing to the control, the comparison of results between different experiments was allowed.

Treatment in a single cultured group of cells was regarded as $\mathrm{n}=1$. Analysis of variance (ANOVA) with a Fisher's post hoc test 

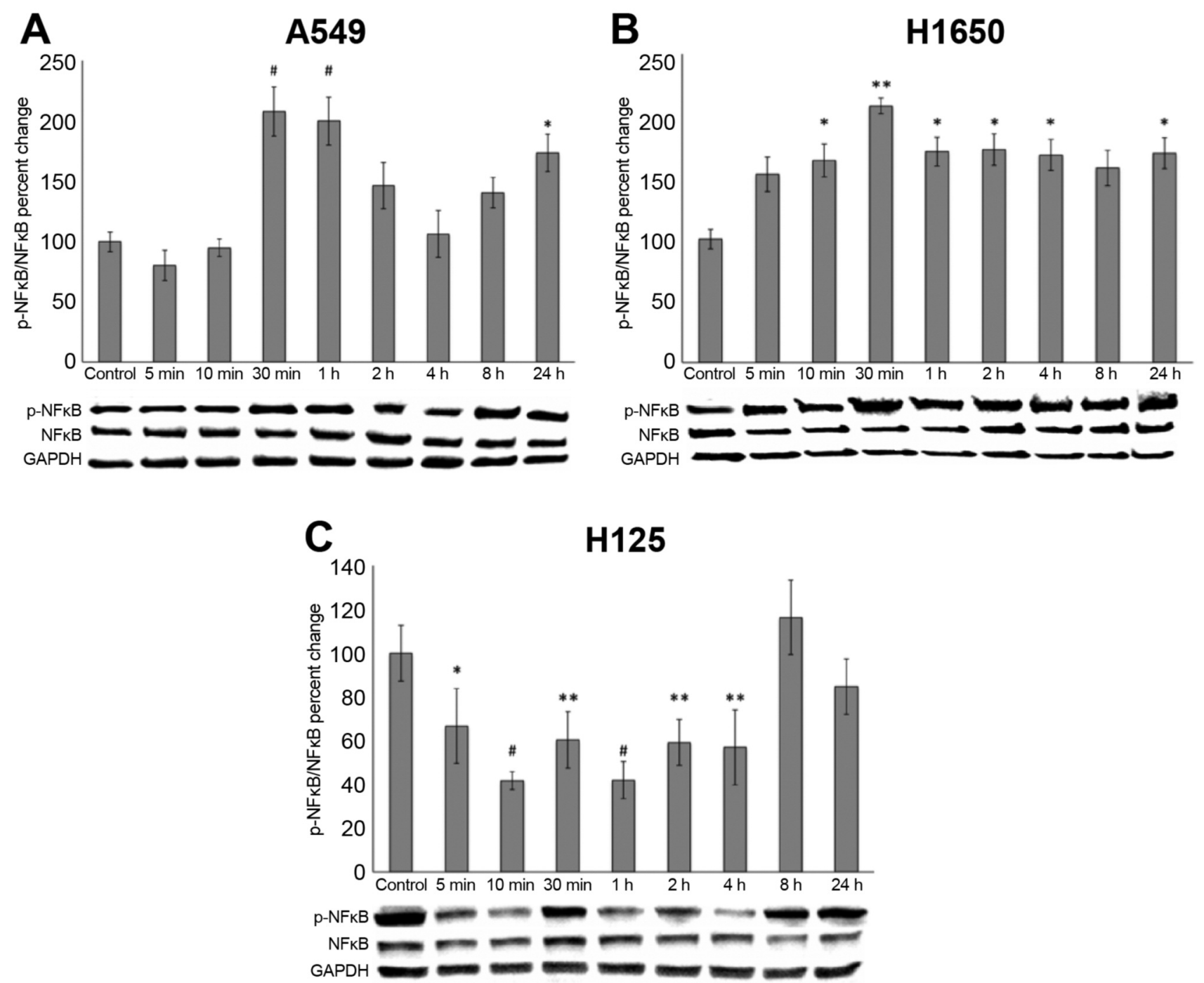

Figure 3. Stimulation with $10 \mu \mathrm{g} / \mathrm{ml}$ Pam3CSK4 led to a peak activation of NF- $\mathrm{KB}$ after $30 \mathrm{~min}$ in A) A549 and B) H1650 adenocarcinoma cells. C) In contrast, $H 125$ adenosquamous cells demonstrated a decrease in $N F-k B$ activity for up to $4 \mathrm{~h}$ following TLR2 stimulation. $n=8 . * p<0.05$, $*^{*} p<0.01, \# p<0.001$ to control. h: Hours; Min: minutes; NF-kB: total nuclear factor kappa B; $p-N F-\kappa B$ : phosphorylated nuclear factor kappa B.

was used to compare 3 or more groups. A $p$-value of $<0.05$ was considered statistically significant and all tests were two-tailed. The standard error of the mean was used for error bar calculations. All histograms and statistical analysis were generated in Microsoft ${ }^{\circledR}$ Excel ${ }^{\circledR}$ (Redmond, WA, USA) and StatPlus:mac Pro (AnalystSoft Inc., Walnut, CA, USA).

\section{Results}

TLR2 is expressed in NSCLC cells. TLR2 expression was readily detectable by western blot analysis in all cell lines (Figure 1). A549 and H1650 cells demonstrated significantly higher levels of baseline TLR2 expression compared to H125 cells $(p<0.001)$. TLR2 expression did not significantly differ between A549 and H1650 cell lines ( $p>0.05)$.
TLR2 activation increases proliferation of human lung adenocarcinoma cells. Treatment with Pam3CSK4 induced proliferation of the adenocarcinoma cell lines A549 and H1650 (Figure 2). The maximal growth rate was seen at a dose of $10 \mu \mathrm{g} / \mathrm{ml}$. Compared to the untreated control, A549 cells showed a $33 \%$ increase in proliferation $(p=0.004)$ and H1650 cells showed a 19\% increase $(p<0.001)$. TLR2 stimulation of $\mathrm{H} 125$ cells resulted in a $16 \%$ decrease in growth rate in response to $10 \mu \mathrm{g} / \mathrm{ml} \operatorname{Pam} 3 \mathrm{CSK} 4(p=0.039)$.

Activation of TLR2 increases $N F-k B$ activity in human lung adenocarcinoma cells. Based on the cell proliferation assay results, we determined $10 \mu \mathrm{g} / \mathrm{ml}$ of Pam3CSK4 to be the optimal dose to treat cell lines. Cells were treated at this dose 


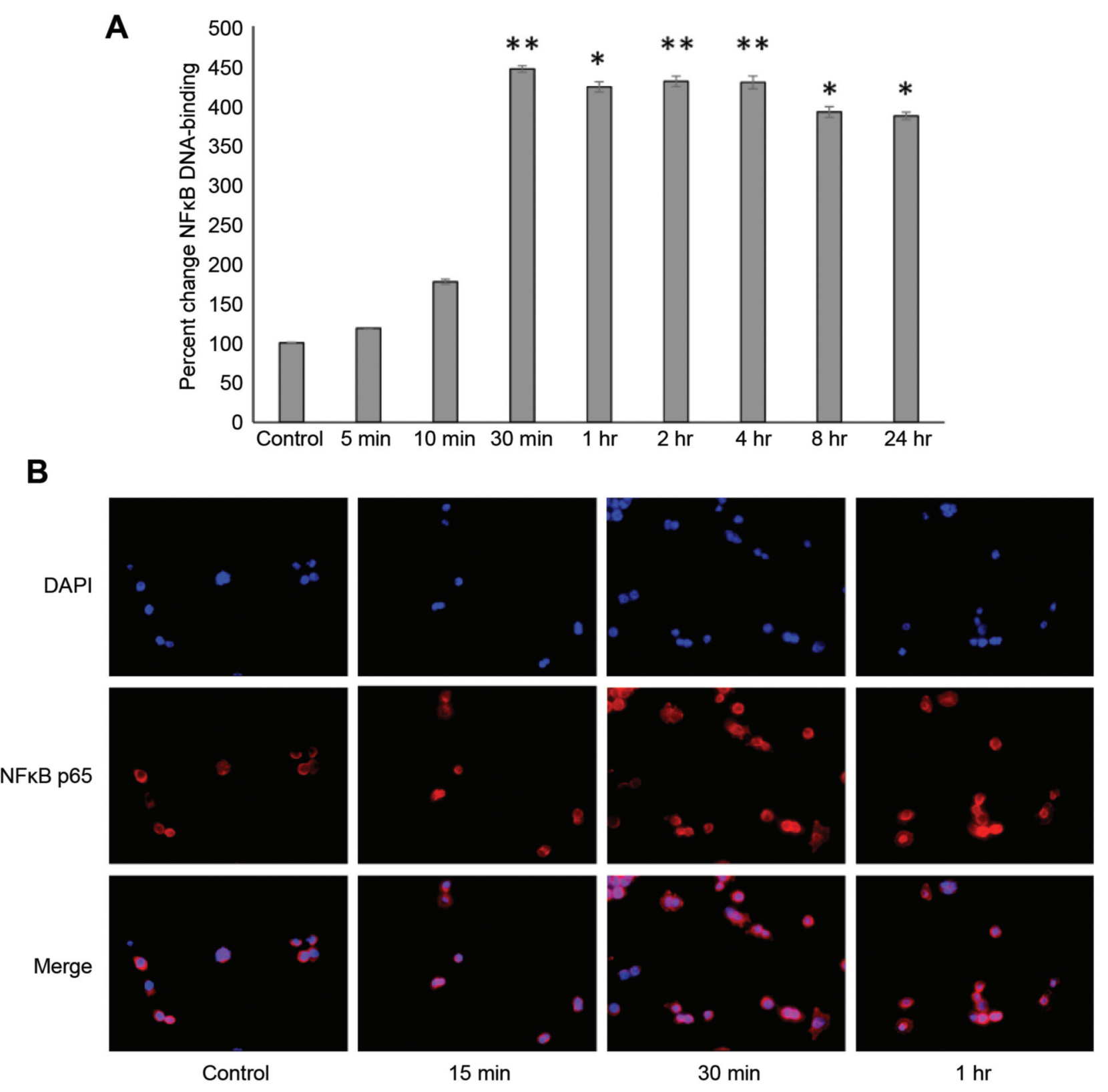

B

Figure 4. Activation of TLR2 increases NF-kB activity in human lung adenocarcinoma cells. A) In A549 adenocarcinoma cells, ELISA results confirmed an increase in $N F-k B$ activation 30 min following TLR2 stimulation as demonstrated by an increase in NF- $k B$ p65 DNA-binding activity. $n=3 .{ }^{*} p<0.05, * * p<0.01$ to control. B) Immunofluorescence analysis demonstrating nuclear translocation of the NF- $k B$ p65 subunit at 30 min in A549 adenocarcinoma cells. Nuclei are stained blue (DAPI) and NF-kB p65 is stained red. $n=1$. DAPI: 4',6-Diamidino-2-phenylindole; H: hour; Min: minutes; $N F-k B$ : total nuclear factor kappa B; TLR2: toll-like receptor 2.

for varying time intervals up to $24 \mathrm{~h}$ and $\mathrm{NF}-\mathrm{kB}$ phosphorylation was assessed (Figure 3 ). NF-kB reached a peak activation in both adenocarcinoma cell lines after 30 $\min$ (A549 $p=0.0003 ;$ H1650 $p=0.0013$ ). The adenosquamous cell line (H125) demonstrated a decrease in NF-kB activity when treated with Pam3CSK 4 at the same dose, with a nadir in activity after $1 \mathrm{~h}(p=0.0006)$.
Using the A549 cell line, we also evaluated NF-kB activation utilizing an ELISA assay to detect DNA-binding activity of NF-kB p65. p65 demonstrated a significant increase in DNA-binding activity after treatment with 10 $\mu \mathrm{g} / \mathrm{ml} \mathrm{Pam3CSK} 4$ for $30 \mathrm{~min}$ ( $p=0.007$; Figure 4A). This result was confirmed by measuring the nuclear translocation of NF-kB p65 via immunofluorescence. A549 cells 
A

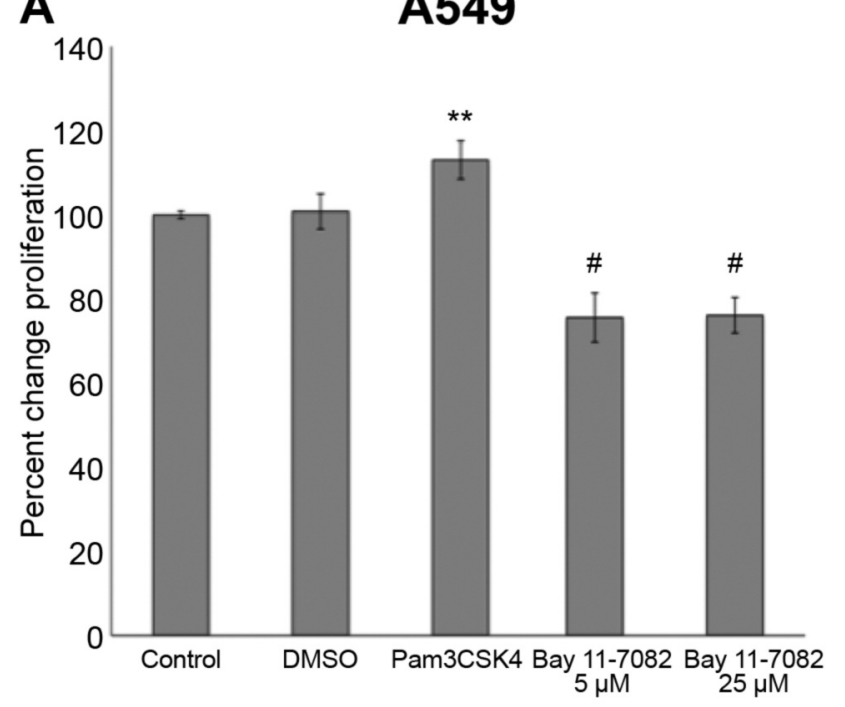

B

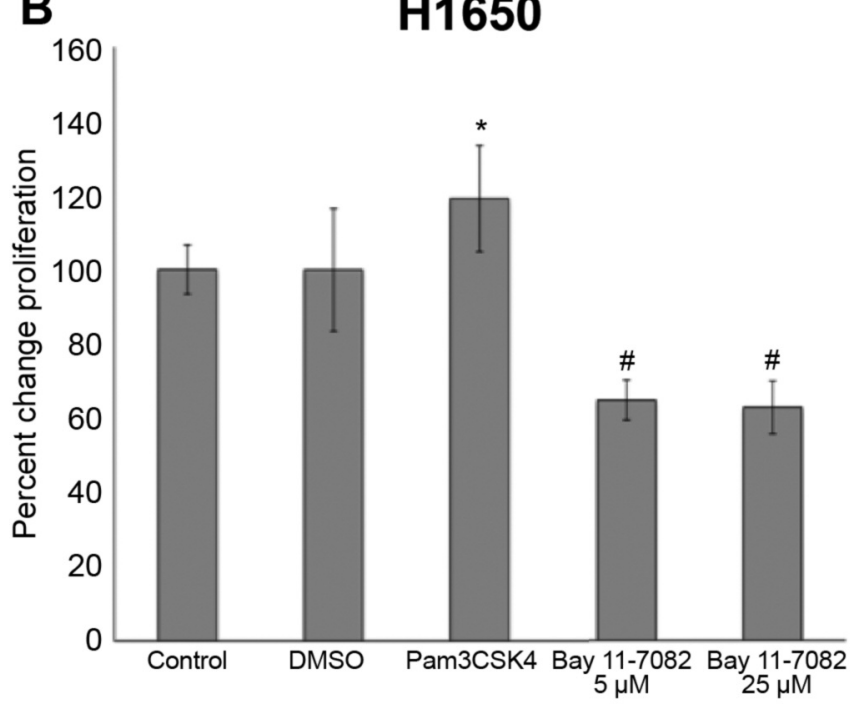

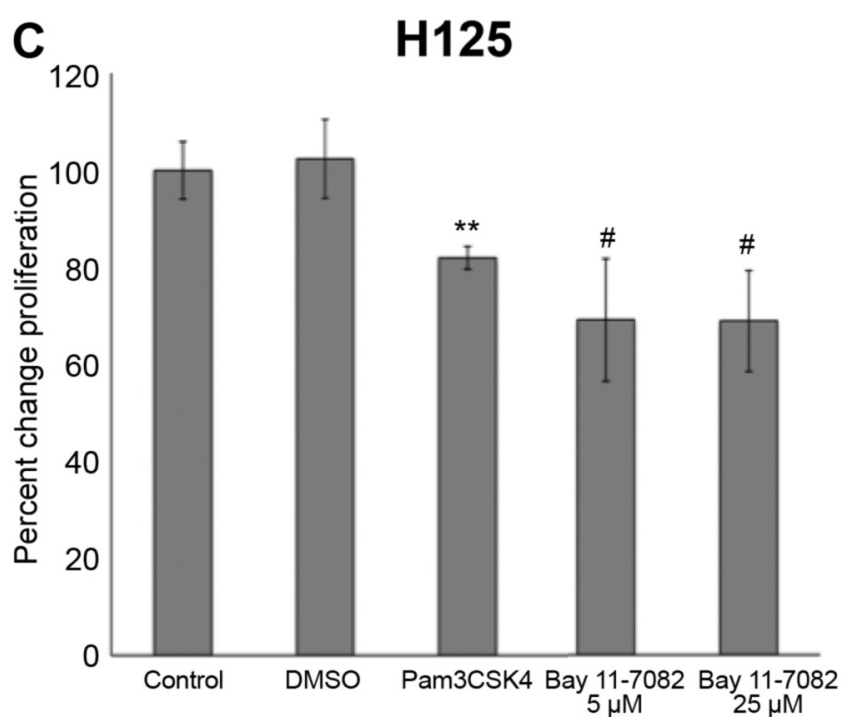

Figure 5. An NF-kB inhibitor (Bay 11-7082) was applied at various concentrations followed by treatment with Pam3CSK4. In A) A549 and B) H1650 adenocarcinoma cells, TLR2 activation significantly increased cell proliferation, while treatment with 5 mM and 10 mM of Bay $11-7082$ significantly mitigated the proliferative response. C) H125 adenosquamous cells showed no increase in proliferation following TLR2 stimulation. $n=6$. ${ }^{*} p<0.05$, **p<0.01 to control; \#p<0.001 to Pam3CSK4. DMSO: Dimethyl sulfoxide; NF-kB: total nuclear factor kappa B; TLR2: toll-like receptor 2 .

demonstrated an increase in NF-kB p65 nuclear concentration between 30 and $60 \mathrm{~min}$ following TLR2 activation with Pam3CSK4 (Figure 4B).

$N F-\kappa B$ inhibition decreases TLR2-mediated proliferation in NSCLC cells. Given that TLR2 stimulation led to increased proliferation and activation of NF-kB, we examined the effect of NF-kB inhibition using Bay 11-7082 in the presence of Pam3CSK4. Cells were pretreated with Bay 11-7082 at increasing doses $(5 \mu \mathrm{M}$ or $25 \mu \mathrm{M})$ for $1 \mathrm{~h}$ and then underwent stimulation with $10 \mu \mathrm{g} / \mathrm{ml}$ Pam3CSK 4 for $48 \mathrm{~h}$.
The MTS proliferation assay demonstrated a significant decrease in the growth rate of all lung cancer cell lines when treated with the NF-kB inhibitor in the presence of the TLR2 agonist. There was no significant difference in proliferation between the untreated control and DMSO vehicle control $(p>0.05)$. When compared to treatment with Pam3CSK 4 alone, A549 cells demonstrated a $38 \%$ reduction in growth rate when treated with Pam3CSK4 plus $5 \mu \mathrm{M}$ Bay 11-7082 $(p<0.0001)$ and a $37 \%$ reduction in growth rate when treated with Pam3CSK4 plus $25 \mu \mathrm{M}$ Bay 11-7082 ( $p<0.0001$; Figure $5 \mathrm{~A})$. H1650 cells demonstrated a $55 \%$ reduction in growth 
rate and $57 \%$ reduction in growth rate when treated with Pam3CSK4 plus $5 \mu \mathrm{M}(p<0.0001)$ and $25 \mu \mathrm{M}(p<0.0001)$ Bay 11-7082, respectively (Figure 5B). H125 cells demonstrated a $13 \%$ reduction in growth rate with Pam3CSK4 plus $5 \mu \mathrm{M}$ Bay 11-7082 $(p=0.03)$ and a $14 \%$ reduction in growth rate with Pam3CSK4 plus $25 \mu \mathrm{M}$ Bay 11-7082 ( $p=0.03$; Figure 5C).

\section{Discussion}

The aim of this study was to determine the impact of TLR2 stimulation on the growth and proliferation of human NSCLC cells as well as to identify the signaling pathway mediating this effect. Our findings indicate the presence of TLR2 in NSCLC cells, with higher levels of expression in adenocarcinoma cell lines compared to a nonadenocarcinoma cell line. Activation of TLR2 by the specific agonist Pam3CSK4 increases the growth rate of lung adenocarcinoma cells, which is mediated by the TLR2/NF$\mathrm{KB}$ pathway. Concurrent stimulation of TLR2 and inhibition of NF-kB led to a decrease in the growth rate of adenocarcinoma cells. These results demonstrate the importance of TLR2 and the NF-kB pathway in the proliferation of lung adenocarcinoma tumor cells.

Our results are consistent with those of recent studies regarding the impact of TLR2 on lung cancer growth. We have reproduced results reported on TLR2 stimulation and increased proliferation in A549 cells (14). In addition to this, we extended the scope of this finding by demonstrating that $\mathrm{NF}-\mathrm{kB}$ is activated in two different adenocarcinoma cell lines upon TLR2 stimulation, and inhibition of this pathway decreases TLR2-mediated cell proliferation. Recent literature demonstrates that several epithelial-derived carcinomas are dependent upon the expression and activation of TLR2 for further progression of disease (23-25). Here, we examined multiple human lung cancer cell lines and identified varying levels of expression of TLR2. Not surprisingly, cell lines with higher levels of TLR2 expression appeared to be more responsive to growth stimulation by a TLR2 agonist. This differing level of expression and correlating effect on proliferation suggests that TLR2 may represent a potential target for therapy, such that tumors that overexpress TLR2 may be candidates for inhibitor treatment.

Growing evidence supports a link between chronic inflammation and carcinogenesis, with an increasing emphasis on the role of TLRs and NF-kB (26-30). A recent study utilizing human tissue samples of intrahepatic cholangiocarcinoma demonstrated that increased TLR2 expression correlated with increased oncologic stage, as well as increased activation of NF-kB (25). In this same study, treatment with NF-kB inhibitor Bay 11-7082 led to inhibition of tumor cell migration and cytokine production. Likewise, multiple studies have shown that expression and activation of TLR2 may contribute to melanoma metastasis $(31,32)$. The direct effects of TLR2 stimulation on the lung tissue and subsequent inflammation have been explored, however few studies to date have evaluated the effects of TLR2 stimulation among different NSCLC subtypes (33).

This study has demonstrated for the first time that, in the presence of a TLR2 agonist, the TLR2/NF-kB signaling pathway is in part responsible for the increased proliferation of human lung adenocarcinoma cells. We demonstrated that $\mathrm{NF}-\mathrm{KB}$ is not only activated, but also undergoes nuclear translocation and DNA binding when TLR2 is stimulated with Pam3CSK4. Furthermore, inhibition of NF-kB resulted in decreased growth of lung adenocarcinoma cells. Some malignancies demonstrate lower levels of TLR2 expression and NF-kB activity in comparison to inflamed, benign tissue of the same type (34). This result is consistent with our nonadenocarcinoma H125 cell line, in which TLR2 stimulation caused both NF-kB suppression and decreased cell growth rate. This could potentially be explained by increased production of anti-inflammatory cytokines (e.g. IL-6, IL-10, TGF- $\beta$ ), decreased production of pro-inflammatory cytokines (e.g. IL-1, IL-12, IL-18, TNF-a), or the activation of other inhibitory processes that occur in response to TLR2 stimulation in this specific NSCLC subtype.

Our findings suggest that further investigation of the TLR2/NF-kB pathway and its impact on proliferation of lung cancer tumor cells is warranted. The downstream effects of TLR2 stimulation should be further evaluated, with a focus on the specific changes in cytokine production that occur across these different NSCLC subtypes. Additionally, further evaluation of the TLR2/NF-kB signaling pathway constituents, including MyD88, IRAK-4, IRAK-1, and TRAF6, amongst others, will provide a better understanding of the downstream effects following TLR2 activation. The use of TLR2/NF-kB antagonists, such as pyrrogallol or $N$ benzylideneaniline derivatives, applied to in vitro and in vivo models may provide future potential therapies for investigation in human clinical trials $(35,36)$.

The results of this study demonstrate that TLR2 stimulation has a direct influence on the growth and proliferation of lung adenocarcinoma cells, which is dependent upon the NF- $\mathrm{kB}$ signaling pathway. In contrast, non-adenocarcinoma cells exhibit lower baseline expression of TLR2 and decreased growth following TLR2 stimulation, which warrants further investigation. TLR2 and NF-kB should continue to be evaluated as important potential therapeutic targets for patients with lung adenocarcinoma.

\section{Conflicts of Interest}

The Authors have no conflicts of interest to disclose in relation to this study. The Authors report no proprietary or commercial interest 
in any product mentioned or concept discussed in this article. This work was funded by the University of Colorado School of Medicine Department of Surgery, Division of Cardiothoracic Surgery. There is no outside funding or grants to report.

\section{Authors' Contributions}

Anna K. Gergen assisted with data analysis and manuscript writing. Patrick D. Kohtz and Alison L. Halpern assisted with data collection and analysis as well as manuscript writing. Anqi Li, Xianzhong Meng, T. Brett Reece, David A. Fullerton, and Michael J. Weyant assisted with project design and manuscript writing.

\section{References}

1 Siegel RL, Miller KD and Jemal A: Cancer statistics, 2020. CA Cancer J Clin 70(1): 7-30, 2020. PMID: 31912902. DOI: $10.3322 /$ caac 21590

2 Lu T, Yang X, Huang Y, Zhao M, Li M, Ma K, Yin J, Zhan C and Wang Q: Trends in the incidence, treatment, and survival of patients with lung cancer in the last four decades. Cancer Manag Res 11: 943-953, 2019. PMID: 30718965. DOI: 10.2147/CMAR. S187317

3 Houston KA, Henley SJ, Li J, White MC and Richards TB: Patterns in lung cancer incidence rates and trends by histologic type in the united states, 2004-2009. Lung Cancer 86(1): 22-28, 2014. PMID: 25172266. DOI: 10.1016/j.lungcan.2014.08.001

4 Wilkinson RW and Leishman AJ: Further advances in cancer immunotherapy: Going beyond checkpoint blockade. Front Immunol 9: 1082, 2018. PMID: 29910800. DOI: 10.3389/ fimmu. 2018.01082

5 Marelli G, Howells A, Lemoine NR and Wang Y: Oncolytic viral therapy and the immune system: A double-edged sword against cancer. Front Immunol 9: 866, 2018. PMID: 29755464. DOI: $10.3389 /$ fimmu.2018.0086

6 Anichini A, Tassi E, Grazia G and Mortarini R: The non-small cell lung cancer immune landscape: Emerging complexity, prognostic relevance and prospective significance in the context of immunotherapy. Cancer Immunol Immunother 67(6): 1011-1022, 2018. PMID: 29516154. DOI: 10.1007/s00262-018-2147-7

7 Attili I, Karachaliou N, Bonanno L, Berenguer J, Bracht J, CodonyServat J, Codony-Servat C, Ito M and Rosell R: Stat3 as a potential immunotherapy biomarker in oncogene-addicted non-small cell lung cancer. Ther Adv Med Oncol 10: 1758835918763744, 2018. PMID: 29636826. DOI: 10.1177/1758835918763744

8 Ioannou S and Voulgarelis M: Toll-like receptors, tissue injury, and tumourigenesis. Mediat Inflam 2010: 581837, 2010. PMID: 20871832. DOI: 10.1155/2010/581837

9 Akira S and Takeda K: Toll-like receptor signalling. Nat Rev Immunol 4(7): 499-511, 2004. PMID: 15229469. DOI: 10.1038/nri1391

10 Fukata M and Abreu MT: Pathogen recognition receptors, cancer and inflammation in the gut. Curr Opin Pharmacol 9(6): 680687, 2009. PMID: 19828376. DOI: 10.1016/j.coph.2009.09.006

11 Kohtz PD, Halpern AL, Eldeiry MA, Hazel K, Kalatardi S, Ao L, Meng X, Reece TB, Fullerton DA and Weyant MJ: Toll-like receptor-4 is a mediator of proliferation in esophageal adenocarcinoma. Ann Thorac Surg 107(1): 233-241, 2019. PMID: 30292843. DOI: 10.1016/j.athoracsur.2018.08.014
12 Kauppila JH and Selander KS: Toll-like receptors in esophageal cancer. Front Immunol 5: 200-200, 2014. PMID: 24847326. DOI: $10.3389 /$ fimmu .2014 .00200

13 Bauer AK, Upham BL, Rondini EA, Tennis MA, Velmuragan K and Wiese D: Toll-like receptor expression in human non-small cell lung carcinoma: Potential prognostic indicators of disease. Oncotarget 8(54): 91860-91875, 2017. PMID: 29190881. DOI: $10.18632 /$ oncotarget.19463

14 Hattar K, Reinert CP, Sibelius U, Gokyildirim MY, Subtil FSB, Wilhelm J, Eul B, Dahlem G, Grimminger F, Seeger W and Grandel U: Lipoteichoic acids from staphylococcus aureus stimulate proliferation of human non-small-cell lung cancer cells in vitro. Cancer Immunol Immunother 66(6): 799-809, 2017. PMID: 28314957. DOI: 10.1007/s00262-017-1980-4

15 Kanzler H, Barrat FJ, Hessel EM and Coffman RL: Therapeutic targeting of innate immunity with toll-like receptor agonists and antagonists. Nat Med 13(5): 552-559, 2007. PMID: 17479101. DOI: $10.1038 / \mathrm{nm} 1589$

16 Pietrocola G, Arciola CR, Rindi S, Di Poto A, Missineo A, Montanaro L and Speziale P: Toll-like receptors (tlrs) in innate immune defense against staphylococcus aureus. Int J Artif Organs 34(9): 799-810, 2011. PMID: 22094559. DOI: 10.5301/ ijao.5000030

17 Gowing SD, Chow SC, Cools-Lartigue JJ, Chen CB, Giannias B, Bourdeau F, Rousseau S, Qureshi ST and Ferri LE: Toll-like receptor activation in bacterial pneumonia increases lung cancer cell adhesion and metastasis formation. Cancer Res 74(19), 2014. PMID: 28401532. DOI: 10.1002/ijc.30734

18 Li X, Wang S, Zhu R, Li H, Han Q and Zhao RC: Lung tumor exosomes induce a pro-inflammatory phenotype in mesenchymal stem cells via nfkappab-tlr signaling pathway. J Hematol Oncol 9: 42, 2016. PMID: 27090786. DOI: 10.1186/s13045-016-0269-y

19 Yu JA, Li H, Meng X, Fullerton DA, Nemenoff RA, Mitchell JD and Weyant MJ: Group iia secretory phospholipase expression correlates with group iia secretory phospholipase inhibition-mediated cell death in k-ras mutant lung cancer cells. J Thorac Cardiovasc Surg 144(6): 1479-1485, 2012. PMID: 23026567. DOI: $10.1016 /$ j.jtcvs.2012.08.064

20 Bennett DT, Reece TB, Foley LS, Sjoberg A, Meng X, Fullerton DA and Weyant MJ: C-terminal tensin-like protein mediates invasion of human lung cancer cells and is regulated by signal transducer and activator of transcription 3. J Thorac Cardiovasc Surg 149(1): 369-375, 2015. PMID: 25439778. DOI: 10.1016/ j.jtcvs.2014.08.087

21 Mauchley D, Meng X, Johnson T, Fullerton DA and Weyant MJ: Modulation of growth in human esophageal adenocarcinoma cells by group iia secretory phospholipase a(2). J Thorac Cardiovasc Surg 139(3): 591-599; discussion 599, 2010. PMID: 20176206. DOI: 10.1016/j.jtcvs.2009.10.061

22 Li F, Song R, Ao L, Reece TB, Cleveland JC, Jr., Dong N, Fullerton DA and Meng X: Adamts5 deficiency in calcified aortic valves is associated with elevated pro-osteogenic activity in valvular interstitial cells. Arterioscler Thromb Vasc Biol 37(7): 1339-1351, 2017. PMID: 28546218. DOI: 10.1161/ ATVBAHA.117.309021

23 Paarnio K, Vayrynen S, Klintrup K, Ohtonen P, Makinen MJ, Makela $\mathrm{J}$ and Karttunen TJ: Divergent expression of bacterial wall sensing toll-like receptors 2 and 4 in colorectal cancer. World J Gastroenterol 23(26): 4831-4838, 2017. PMID: 28765705. DOI: $10.3748 / w j g . v 23 . i 26.4831$ 
24 West AC, Tang K, Tye H, Yu L, Deng N, Najdovska M, Lin SJ, Balic JJ, Okochi-Takada E, McGuirk P, Keogh B, McCormack W, Bhathal PS, Reilly M, Oshima M, Ushijima T, Tan P and Jenkins BJ: Identification of a tlr2-regulated gene signature associated with tumor cell growth in gastric cancer. Oncogene 36(36): 5134-5144, 2017. PMID: 28481875. DOI: 10.1038/onc. 2017.121

25 Liu B, Yan S, Jia Y, Ma J, Wu S, Xu Y, Shang M and Mao A: Tlr2 promotes human intrahepatic cholangiocarcinoma cell migration and invasion by modulating nf-kappab pathwaymediated inflammatory responses. FEBS J 283(20): 3839-3850, 2016. PMID: 27616304. DOI: 10.1111/febs.13894

26 Balkwill F and Coussens LM: Cancer: An inflammatory link. Nature 431(7007): 405-406, 2004. PMID: 15385993. DOI: $10.1038 / 431405 \mathrm{a}$

27 Coussens LM and Werb Z: Inflammation and cancer. Nature 420(6917): 860-867, 2002. PMID: 12490959. DOI: 10.1038/ nature 01322

28 Demaria S, Pikarsky E, Karin M, Coussens LM, Chen YC, ElOmar EM, Trinchieri G, Dubinett SM, Mao JT, Szabo E, Krieg A, Weiner GJ, Fox BA, Coukos G, Wang E, Abraham RT, Carbone $\mathrm{M}$ and Lotze MT: Cancer and inflammation: Promise for biologic therapy. J Immunother 33(4): 335-351, 2010. PMID: 20386472. DOI: 10.1097/CJI.0b013e3181d32e 74

29 Gu J, Liu Y, Xie B, Ye P, Huang J and Lu Z: Roles of toll-like receptors: From inflammation to lung cancer progression. Biomed Rep 8(2): 126-132, 2018. PMID: 29435270. DOI: 10.3892/br.2017.1034

30 Ben-Neriah Y and Karin M: Inflammation meets cancer, with NF-Kappab as the matchmaker. Nat Immunol 12(8): 715-723, 2011. PMID: 21772280. DOI: 10.1038/ni.2060.

31 Yang HZ, Cui B, Liu HZ, Mi S, Yan J, Yan HM, Hua F, Lin H, Cai WF, Xie WJ, Lv XX, Wang XX, Xin BM, Zhan QM and Hu ZW: Blocking tlr2 activity attenuates pulmonary metastases of tumor. PLoS One 4(8): e6520, 2009. PMID: 19654875. DOI: 10.1371 /journal.pone. 0006520
32 Yan J, Hua F, Liu HZ, Yang HZ and Hu ZW: Simultaneous tlr2 inhibition and tlr9 activation synergistically suppress tumor metastasis in mice. Acta Pharmacol Sin 33(4): 503-512, 2012. PMID: 22426694. DOI: 10.1038/aps.2011.193

33 Wang L, Wang M, Li S, Wu H, Shen Q, Zhang S, Fang L and Liu R: Nebulized lidocaine ameliorates allergic airway inflammation via downregulation of tlr2. Mol Immunol 97: 94100, 2018. PMID: 29609129. DOI: 10.1016/j.molimm. 2018.03.010

34 Soares JB, Pimentel-Nunes P, Afonso L, Rolanda C, Lopes P, Roncon-Albuquerque R Jr., Goncalves N, Boal-Carvalho I, Pardal F, Lopes S, Macedo G, Lara-Santos L, Henrique R, Moreira-Dias L, Goncalves R, Dinis-Ribeiro M and LeiteMoreira AF: Increased hepatic expression of tlr2 and tlr 4 in the hepatic inflammation-fibrosis-carcinoma sequence. Innate Immun 18(5): 700-708, 2012. PMID: 22330637. DOI: 10.1177/ 1753425912436762

35 Grabowski M, Murgueitio MS, Bermudez M, Rademann J, Wolber $G$ and Weindl G: Identification of a pyrrogallol derivative as a potent and selective human tlr2 antagonist by structure-based virtual screening. Biochem Pharmacol, 2018. PMID: 29684378. DOI: 10.1016/j.bcp.2018.04.018

36 Cai S, Zhu G, Cen X, Bi J, Zhang J, Tang X, Chen K and Cheng $\mathrm{K}$ : Synthesis, structure-activity relationships and preliminary mechanism study of n-benzylideneaniline derivatives as potential tlr2 inhibitors. Bioorg Med Chem 26(8): 2041-2050, 2018. PMID: 29534935. DOI: 10.1016/j.bmc.2018.03.001

Received June 26, 2020

Revised July 14, 2020

Accepted July 15, 2020 